\title{
Causes and Effects of Cost Overrun on Construction Project in Bahrain: Part I (Ranking of Cost Overrun Factors and Risk Mapping)
}

\author{
Hedaya A. M. Abusafiya ${ }^{1} \&$ Saad M. A. Suliman $^{1}$ \\ ${ }^{1}$ Department of Mechanical Engineering, University of Bahrain, Kingdom of Bahrain \\ Correspondence: Hedaya A. M. Abusafiya, Department of Mechanical Engineering, University of Bahrain, \\ Kingdom of Bahrain. E-mail: Hedaya.abusafiya@hotmail.com
}

Received: December 10, 2016

Accepted: December 30, 2016 Online Published: May 27, 2017

doi: $10.5539 /$ mas.v11n 7 p20

URL: https://doi.org/10.5539/mas.v11n7p20

\begin{abstract}
Cost performance is one of the basic criteria for measuring construction project success. Despite its proven importance it is not uncommon to see a construction project failing to achieve its objectives within the specified cost. The paper attempts to identify the major causes of cost overrun in Bahrain construction sector, and to assess the effect of these causes on cost overrun. A list of these causes was collected through an extensive literature review, historical construction projects records and expert opinions. In total 45 factors were short-listed to be made part of questionnaire used in a survey conducted with representatives from local contracting, consulting, and client firms. Findings are presented in form of tables that classify cost overrun factors, and their ranking. The overall results showed that frequent design changes, mistakes during construction, and schedule delay were considered as the most important factors of cost overrun causes in Bahrain construction industry.
\end{abstract}

Key words: Cost Overrun, Cost Overrun Factors, Construction Industry

\section{Introduction}

The construction industry is the engine of national economy through which the total of physical development is achieved. The construction industry has also a significant effect on the efficiency and productivity of other industry sectors. One cannot think of widespread investment in manufacturing, agriculture, or service sectors unless the construction results of facilities are in place. In Bahrain the construction sector contributed $10.7 \%$ to growth of real GDP in 2014. After social and personal services sector, it was in the second rank of the fastest growth sectors in Bahrain non oil economy, the sector grew by 7.3\% in 2014 from 2013, and this growth is mainly attributed to the prioritization of infrastructure and housing projects in the kingdom. The main goal for this industry is to achieve timely completion of projects within stipulated budget and required quality. Oddly though; nine out of ten construction projects overrun their budget, with an $86 \%$ probability of outrunning their set cost targets, and no learning that would improve cost estimate accuracy seems to take place as the size of overruns have not improved over the last 70 years according to Flyvbjerg et al. $(2002,2003)$. Bahrain is not an exception, although there are few researches available, Bahrain is facing a serious issue of cost overrun in construction industry. This is confirmed with the large number of construction projects failed to proceed, and the serious concern of investors, which needs an in-depth research to put forward with solution to this issue.

The cost estimated in the initial stage of a project is very important. It carries far more economic consequences than the limited decisions which can be made later. Effective cost estimation is therefore so vital, because it can determine a project's financial fate. An out of control construction cost adds to investment pressure, increases construction cost, affects investment decision-making and wastes the national finance. That being the case, it is not difficult to appreciate the need for a solution to this problem, for greater estimate reliability at all stages of a project and for greater assurance that initial cost expectations are met. Hence, there is a need to understand the causes of these overruns on projects, as identifying and understanding the causes are usually the first step when addressing a problem; and then corrective actions can be taken.

This paper aims to identify and rank the main causes of cost overrun based on their overall effects on building construction projects in Bahrain. The following analysis methods were set to maximize the chances of achieving this objective. 
- identify each factor risk zone by creating a risk map for cost overrun factors using severity and frequency indices.

- rank of the factors affecting cost overrun in building construction in Bahrain using the importance index.

\section{Literature Review}

Recently it has been witnessed that a large number of construction projects are facing the problem of cost overrun, which is associated with some form of risk and uncertainty in the project. Such associated risks may be of various kinds which depend on many factors, due to the uniqueness, complexity and dynamic nature of the construction activities. Arditi, et al. (1985) conducted a study in Turkey to understand the main reasons for cost overruns in projects that were constructed between the 1970s and the 1980s. The authors attributed the main causes of cost overruns to the increase of materials prices, fast growth of inflation, and delays caused by changes in design specification. Okpala and Aniekwu (1988) searched for the main causes of high costs of construction projects in Nigeria, and found that the main causes of cost overruns were shortage of materials, finance and payment for completed works, poor contract management, price fluctuations and fraudulent practices. In another study from Nigeria, conducted by Elinwa and Buba (1993), they found that the material cost, fraudulent practices, materials prices increment, high cost of machineries and poor planning were the most important causes of cost overruns. Koushki, et al. (2004) carried out a study about delays and cost increases in the construction of private residential projects in Kuwait, it aimed to find the reasons for delays and cost increases in the construction projects from the standpoint of the owner. The authors concluded the main causes of cost overruns as increase of materials cost, poor contractor management, inaccurate estimation of the degree of complexity of works and owners' financial constraints. In the UK a study by Jackson (2002) was carried out to find the most important factors causing cost overrun, and they were identified as poor project planning and management, unexpected ground condition, design development, lack of information, estimating method, and time limit. Le-Hoai et al, (2008) adopted field survey methodology to identify the delay and cost overrun factors in Vietnamese construction market, the authors found that poor site management and supervision, contractor poor project management assistance, consultant financial difficulties of owner, contractor design changes, project unforeseen site conditions, owner inaccurate estimates and consultant poor contract management were the most critical cost overrun factors.

The literature review aimed to identify and assess various factors responsible for the cost overrun, which require serious attention to understand and address. a total of 45 factors of cost overrun were selected from the literature to be investigated in this paper, These factors were classified into 8 groups, named as Contractor's Site Management Related Factors (CSM), Design and Documentation Related Factors (DDF), Financial Management Related Factors (FIN), Information and Communication Related Factors (ICT), Human Resource Related Factors (HR), Non-human Resource Related Factors (NHR), Project Management and Contract Administration (PMCA), and Environmental Related Factors (EV). Table 1 shows the factors of each of these groups.

Table 1. Selected Groups and Factors of Cost Overrun

\begin{tabular}{|c|c|}
\hline $\begin{array}{l}\text { Project Management and Contract Administration } \\
\text { Related Factors (PMCA): }\end{array}$ & Design and Documentation Related Factors(DDF): \\
\hline Poor project management (PPM) & Frequent design changes \\
\hline Change in the scope of the project (CSP) & Mistakes and errors in design \\
\hline Delays in decisions making (DDM) & Incomplete design at the time of tender \\
\hline Inaccurate quantity take-off (IQT) & Poor design and delays in design \\
\hline & Delay preparation and approval of drawings \\
\hline Contractor's Site Management Related Factors(CSM): & Financial Management Related Factors (FIN): \\
\hline Poor site management and supervision & 18 Cash flow \\
\hline Incompetent subcontractors & 19 Poor financial control on site \\
\hline Schedule delay & 20 Financial difficulties of owner \\
\hline Inadequate planning and scheduling & 21 Delay in progress payment by owner \\
\hline Lack of experience & 22 Delay payment to supplier/subcontractor \\
\hline Inaccurate time and cost estimates & 23 Contractual claims \\
\hline Mistakes during construction & \\
\hline Inadequate monitoring and control & \\
\hline Information and Communication Related Factors(ICT): & \multirow{2}{*}{$\begin{array}{l}\text { Human Resources (Workforce) Related Factors(HR): } \\
27 \text { Labour productivity }\end{array}$} \\
\hline Lack of coordination between parties & \\
\hline
\end{tabular}




\begin{tabular}{llll}
\hline 25 & Slow information flow between parties & 28 & Shortage of site workers \\
26 & Lack of communication between parties & 29 & Shortage of technical personnel \\
& & 30 & High cost of labour \\
& 31 & Labour absenteeism \\
\hline Non-Human Resource Related Factors(NHR): & Environmental Related Factors(EV): \\
\hline 32 & Fluctuation of prices of materials & 36 & Level and number of competitors \\
33 & Shortages of materials & 37 & economic instability \\
34 & Equipment availability and failure & 38 & effects of weather \\
35 & Late delivery of materials and equipment & 39 & government policies \\
& 40 & inadequate production of raw materials by the \\
& 41 & montry \\
& 42 & number of projects going at the same time \\
& 43 & political situation \\
& 44 & project location \\
& 45 & Social and cultural impacts \\
\hline
\end{tabular}

\section{Methodology}

Data was collected through a mixed methodology of quantitative method (Survey), and semi-qualitative methods (interviews and actual projects data). The questionnaire was prepared to find the frequency and severity of cost overrun experienced by practitioners, the causes of cost overrun in their opinions, and the factors that help to effectively control their projects. Construction projects historical records were collected from some construction companies in Bahrain, and the concerned practitioners involved in projects were interviewed to obtain the estimated and the actual cost, and define the direct and indirect causes of construction projects cost overrun (if any).

\subsection{Questionnaire Design}

Survey was performed by questionnaire method, where a list of different types of closed ended and open ended questions, were answered by professional practitioners' engineers, in public and private sectors in Bahrain. The questionnaire contained three sections. The first section aimed to collect the background information of the respondent. The second section included the respondents' opinion on the risk factor in terms of its likelihood and impact to overall construction project success. A five-point scale of 1 to 5 was considered for evaluating each factor, these numerical impact and likelihood values were assigned to the respondents' rating: (1: Not significant; 2: Slightly significant; 3: Moderate; 4: Very significant; 5: Extremely significant). The third section included the respondent's additions and comments on the risk of cost overrun for construction projects in Bahrain. The questionnaire was sent out to a total of 103 engineers of different levels of work experiences, asking for their contribution in this study; a total of 74 engineers were willing to participate and have filled the questionnaire. The response rate was $71.8 \%$, including 42 contractors, 21 consultants and 11 clients.

\subsection{Actual Projects Data}

Cost overrun occurs when the actual cost for the project is more than the estimated cost. In this part, forty building construction projects were evaluated. The projects were selected based on the types of the projects and availability of estimated and actual cost data. Selected project types were new construction, reconstruction and improvement of existing facilities. Forty seven and half percent of the projects were mainly houses, and residential buildings, other projects included general (utility buildings) 20\%, health (hospitals and clinics) $10 \%$, educational (schools, kindergartens and institutes, etc.) $17.5 \%$, and sports and youth projects $5 \%$.

\subsection{Results and Analysis}

The questionnaire results are complied to obtain the frequencies of each factor (FI(i)) across all the respondees, and similarly their severities (SI(i)). Hence, frequency and severity indices of the various factors responsible for project cost overrun are calculated using the following formulae: 


$$
\begin{aligned}
& \text { Survey based frequency index (FI (i)) }=\frac{\sum_{w_{i}=1}^{5} w_{i} \times f_{i}}{5 \times N} \\
& \text { Survey based severity index (SI (i)) } \quad=\frac{\sum_{w_{i}=1}^{5} w_{i} \times S_{i}}{5 \times N}
\end{aligned}
$$

Where, $\mathbf{w}_{\mathbf{i}}$ is a constant representing weight assigned to factor $\mathrm{i}$ (ranges from 5 for Extremely Significant/Continual to 1 for Not Significant); $\mathbf{f}_{\mathbf{i}}$ and $\mathbf{s}_{\mathbf{i}}$ are the frequency and severity of factor(i); respectively; $\mathbf{N}$ is the total number of responses.

The actual data results are also complied to obtain the actual data based severities across all evaluated projects. Thus, the actual data based frequency index (FI'(i)) of factor (i) is given by:

$$
\text { FI'(i) }=(\text { Factor }(\mathrm{i}) \text { incidences across all projects }) /(\text { total number of projects })
$$

The actual data based severity index (SI'(i)) of factor (i) is given by:

$$
\text { SI'(i) }=(\text { Sum of factor }(i) \text { severities/number of projects experienced this factor })
$$

Where factor (i) severity is driven by the formula and Table 2 below,

$$
\text { Percentage of cost overrun }=\quad \frac{\text { Estimated project cost }- \text { Actual project cost }}{\text { Actual project cost }}
$$

Table 2. Actual Projects Degree of Severity

\begin{tabular}{lr}
\hline Percentage of Cost Overrun (\%) & Degree of Severity \\
\hline Less than 2\% & 1 \\
$2-5 \%$ & 2 \\
$5-7 \%$ & 3 \\
$7-10 \%$ & 4 \\
Greater than 10\% & 5 \\
*Bahrain Construction Project Contingency 5-10\% & \\
\hline
\end{tabular}

\section{Risk Mapping}

The Risk map is a two-dimensioned matrix classifies risks into three categories based on the combined effects of their frequency and severity. It helps in classifying risks into one of five states of likelihood and into five states of consequence (minimal through unacceptable). Table 3 shows the scale used to determine the severity and frequency levels for cost overrun factors. Standard risk map is used to determine the risk zone for each cost overrun factor. The map is a five by five matrix with severity ranging from very low (VL) to very high (VH) on the horizontal axis and frequency with the same range on the vertical axis. Three zones were presented in the map, that classifies a risk as either "high" (red), "moderate" (yellow), or "low" (green), as shown in Figure 1 The zones have the following characteristics. (FHWA, 2007).

1. Green zone: Minimum impact. Minimum oversight needed to ensure risk remains low.

2. Yellow zone: It can cause some disruption. Different approach may be required to reduce it and additional management attention may be needed to control it.

3. Red zone: Unacceptable, major disruption likely. Different approach required with priority management attention.

Table 3. Scale Used to Identify Severity and Frequency Level and Associated Effect on Cost (FHWA, 2007)

\begin{tabular}{lllll}
\hline Level & Index value (Scale) & Severity & Frequency & Effect on Cost \\
\hline A & $\leq 20 \%$ & very low $(\mathrm{VL})$ & very low $(\mathrm{VL})$ & Minimal or no impact \\
B & $20 \%-40 \%$ & low $(\mathrm{L})$ & low $(\mathrm{L})$ & $<5 \%$ \\
C & $40 \%-60 \%$ & moderate $(\mathrm{M})$ & moderate $(\mathrm{M})$ & $5-7 \%$ \\
D & $60 \%-80 \%$ & high $(\mathrm{H})$ & high $(\mathrm{H})$ & $7-10 \%$ \\
E & $80 \%-100 \%$ & very high $(\mathrm{VH})$ & very high $(\mathrm{VH})$ & $>10 \%$ \\
\hline
\end{tabular}




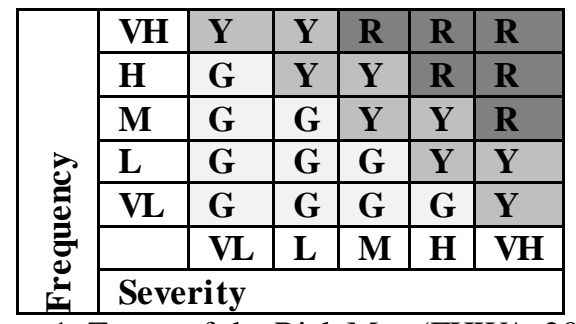

Figure 1. Zones of the Risk Map (FHWA, 2007)

Both survey and actual data risk mapping results were established for the 45 cost overrun factors. Table 4 shows some factors that had zone agreement by the two approaches; others did not, therefore the average results (survey and actual data) were calculated and new risk map was introduced. Column eight in Table 4 shows the risk mapping of combined results.

Table 4. Risk Mapping for Survey, Actual and Combined Cost Overrun Factors

\begin{tabular}{|c|c|c|c|c|c|c|c|c|c|c|c|c|}
\hline \multicolumn{2}{|l|}{ Factors } & \multicolumn{2}{|c|}{$\begin{array}{l}\text { Severity } \\
\text { Index }\end{array}$} & \multicolumn{2}{|c|}{$\begin{array}{l}\text { Severity } \\
\text { level }\end{array}$} & \multicolumn{2}{|c|}{$\begin{array}{l}\text { Frequency } \\
\text { index }\end{array}$} & \multicolumn{2}{|c|}{$\begin{array}{l}\text { Frequency } \\
\text { level }\end{array}$} & \multirow{2}{*}{$\begin{array}{l}\text { Survey } \\
\text { Map } \\
\text { zone }\end{array}$} & \multirow{2}{*}{$\begin{array}{l}\text { Actual } \\
\text { Data } \\
\text { Map } \\
\text { zone }\end{array}$} & \multirow{2}{*}{$\begin{array}{l}\text { Combined } \\
\text { Map zone }\end{array}$} \\
\hline Code & Description & $\mathbf{S}^{*}$ & $\mathbf{A}^{* *}$ & $\mathbf{S}$ & $\mathbf{A}$ & $\mathbf{S}$ & $\mathbf{A}$ & $\mathbf{S}$ & $\mathbf{A}$ & & & \\
\hline PPM & Poor project management & 72.43 & 60 & $\mathrm{H}$ & $\mathrm{H}$ & 73.24 & 60 & $\mathrm{H}$ & $\mathrm{H}$ & Red & Red & Red \\
\hline CSP & Change in the scope of the project & 59.19 & 100 & $\mathrm{M}$ & $\mathrm{VH}$ & 57.84 & 40 & $\mathrm{M}$ & $\mathrm{M}$ & Yellow & Red & Yellow \\
\hline DDM & Delays in decisions making & 51.62 & 65 & $\mathrm{M}$ & $\mathrm{H}$ & 51.43 & 100 & $\mathrm{M}$ & $\mathrm{VH}$ & Yellow & Red & Yellow \\
\hline IQT & Inaccurate quantity take-off & 71.08 & 65 & $\mathrm{H}$ & $\mathrm{H}$ & 74.59 & 100 & $\mathrm{H}$ & $\mathrm{VH}$ & Red & Red & Red \\
\hline FDC & Frequent design changes & 88.38 & 60 & $\mathrm{VH}$ & $\mathrm{H}$ & 86.49 & 100 & $\mathrm{VH}$ & $\mathrm{VH}$ & Red & Red & Red \\
\hline MED & Mistakes and errors in design & 78.92 & 66.67 & $\mathrm{H}$ & $\mathrm{H}$ & 44.59 & 80 & M & $\mathrm{VH}$ & Yellow & Red & Red \\
\hline IDTT & Incomplete design at the time of tender & 67.03 & 50 & $\mathrm{H}$ & M & 67.03 & 100 & $\mathrm{H}$ & $\mathrm{VH}$ & Red & Red & Red \\
\hline PDDD & Poor design and delays in design & 75.95 & 70 & $\mathrm{H}$ & $\mathrm{H}$ & 45.95 & 40 & M & $\mathrm{M}$ & Yellow & Yellow & Yellow \\
\hline DPAD & Delay preparation and approval of drawings & 63.51 & 100 & $\mathrm{H}$ & $\mathrm{VH}$ & 73.78 & 40 & $\mathrm{H}$ & $\mathrm{M}$ & Red & Red & Red \\
\hline PSMS & Poor site management and supervision & 69.73 & 66.67 & $\mathrm{H}$ & $\mathrm{H}$ & 74.32 & 100 & $\mathrm{H}$ & $\mathrm{VH}$ & Red & Red & Red \\
\hline IS & Incompetent subcontractors & 80.54 & 0 & $\mathrm{VH}$ & $\mathrm{VL}$ & 59.46 & 0 & M & $\mathrm{VL}$ & Red & Green & Green \\
\hline SD & Schedule delay & 87.57 & 51.43 & $\mathrm{VH}$ & $\mathrm{M}$ & 77.03 & 100 & $\mathrm{H}$ & $\mathrm{VH}$ & Red & Red & Red \\
\hline IPS & Inadequate planning and scheduling & 78.65 & 25 & $\mathrm{H}$ & $\mathrm{L}$ & 62.43 & 100 & $\mathrm{H}$ & $\mathrm{VH}$ & Red & Yellow & Red \\
\hline LOE & Lack of experience & 79.73 & 45 & $\mathrm{H}$ & M & 55.14 & 100 & M & $\mathrm{VH}$ & Yellow & Red & Red \\
\hline ITCE & Inaccurate time and cost estimates & 92.97 & 60 & $\mathrm{VH}$ & $\mathrm{H}$ & 60.27 & 100 & $\mathrm{H}$ & $\mathrm{VH}$ & Red & Red & Red \\
\hline MDC & Mistakes during construction & 90.27 & 70 & $\mathrm{VH}$ & $\mathrm{H}$ & 64.32 & 100 & $\mathrm{H}$ & $\mathrm{VH}$ & Red & Red & Red \\
\hline $\mathrm{IMC}$ & Inadequate monitoring and control & 77.03 & 30 & $\mathrm{H}$ & $\mathrm{L}$ & 62.7 & 60 & $\mathrm{H}$ & $\mathrm{H}$ & Red & Yellow & Yellow \\
\hline $\mathrm{CF}$ & Cash flow & 60.54 & 55 & $\mathrm{H}$ & M & 48.92 & 100 & M & $\mathrm{VH}$ & Yellow & Red & Yellow \\
\hline PFCS & Poor financial control on site & 59.46 & 40 & $\mathrm{M}$ & M & 44.86 & 40 & M & M & Yellow & Yellow & Yellow \\
\hline FDO & Financial difficulties of owner & 49.19 & 0 & $\mathrm{M}$ & $\mathrm{VL}$ & 59.73 & 0 & $\mathrm{M}$ & $\mathrm{VL}$ & Yellow & Green & Green \\
\hline DPPO & Delay in progress payment by owner & 55.41 & 66.67 & $\mathrm{M}$ & $\mathrm{H}$ & 58.11 & 80 & $\mathrm{M}$ & $\mathrm{VH}$ & Yellow & Red & Red \\
\hline DPS & Delay payment to supplier/subcontractor & 65.14 & 50 & $\mathrm{H}$ & M & 64.86 & 60 & $\mathrm{H}$ & $\mathrm{H}$ & Red & Yellow & Yellow \\
\hline $\mathrm{CC}$ & Contractual claims & 57.3 & 80 & $\mathrm{M}$ & $\mathrm{VH}$ & 45.14 & 40 & M & $\mathrm{M}$ & Yellow & Red & Yellow \\
\hline LCOP & Lack of coordination between parties & 58.92 & 70 & $\mathrm{M}$ & $\mathrm{H}$ & 57.57 & 60 & $\mathrm{M}$ & $\mathrm{H}$ & Yellow & Red & Yellow \\
\hline SIFP & Slow information flow between parties & 55.41 & 30 & $\mathrm{M}$ & $\mathrm{L}$ & 58.38 & 60 & $\mathrm{M}$ & $\mathrm{H}$ & Yellow & Yellow & Yellow \\
\hline LCMP & Lack of communication between parties & 59.46 & 80 & $\mathrm{M}$ & $\mathrm{VH}$ & 54.59 & 40 & $\mathrm{M}$ & $\mathrm{M}$ & Yellow & Red & Yellow \\
\hline LP & Labour productivity & 80 & 60 & $\mathrm{VH}$ & $\mathrm{H}$ & 70.54 & 60 & $\mathrm{H}$ & $\mathrm{H}$ & Red & Red & Red \\
\hline SSW & Shortage of site workers & 78.38 & 52 & $\mathrm{H}$ & $\mathrm{M}$ & 69.46 & 100 & $\mathrm{H}$ & $\mathrm{VH}$ & Red & Red & Red \\
\hline STP & Shortage of technical personnel & 76.49 & 20 & $\mathrm{H}$ & $\mathrm{L}$ & 47.03 & 40 & $\mathrm{M}$ & $\mathrm{M}$ & Yellow & Green & Yellow \\
\hline $\mathrm{HCL}$ & High cost of labour & 69.73 & 60 & $\mathrm{H}$ & $\mathrm{H}$ & 48.92 & 60 & $\mathrm{M}$ & $\mathrm{H}$ & Yellow & Red & Yellow \\
\hline LA & Labour absenteeism & 70 & 60 & $\mathrm{H}$ & $\mathrm{H}$ & 42.7 & 40 & $\mathrm{M}$ & M & Yellow & Yellow & Yellow \\
\hline FPM & Fluctuation of prices of materials & 83.51 & 0 & VH & VL & 45.95 & 0 & $\mathrm{M}$ & $\mathrm{VL}$ & Red & Green & Green \\
\hline $\mathrm{SM}$ & Shortages of materials & 82.43 & 30 & $\mathrm{VH}$ & $\mathrm{L}$ & 41.89 & 100 & $\mathrm{M}$ & $\mathrm{VH}$ & Red & Yellow & Yellow \\
\hline EAF & Equipment availability and failure & 76.76 & 20 & $\mathrm{H}$ & $\mathrm{L}$ & 39.73 & 40 & $\mathrm{~L}$ & M & Yellow & Green & Green \\
\hline
\end{tabular}




\begin{tabular}{|l|l|l|l|l|l|l|l|l|l|l|l|l|} 
LDME & Late delivery of materials and equipment & 81.08 & 53.33 & $\mathrm{VH}$ & $\mathrm{M}$ & 53.24 & 80 & $\mathrm{M}$ & $\mathrm{VH}$ & Red & Red & Red \\
\hline LNC & Level and number of competitors & 69.73 & 20 & $\mathrm{H}$ & $\mathrm{L}$ & 64.86 & 40 & $\mathrm{H}$ & $\mathrm{M}$ & Red & Green & Yellow \\
\hline EI & economic instability & 63.24 & 0 & $\mathrm{H}$ & $\mathrm{VL}$ & 51.08 & 0 & $\mathrm{M}$ & $\mathrm{VL}$ & Yellow & Green & Green \\
\hline EW & effects of weather & 60.81 & 40 & $\mathrm{H}$ & $\mathrm{M}$ & 38.38 & 40 & $\mathrm{~L}$ & $\mathrm{M}$ & Yellow & Yellow & Green \\
\hline GP & government policies & 46.76 & 0 & $\mathrm{M}$ & $\mathrm{VL}$ & 40.81 & 0 & $\mathrm{M}$ & $\mathrm{VL}$ & Yellow & Green & Green \\
\hline IPRM & $\begin{array}{l}\text { inadequate production of raw materials by } \\
\text { the country }\end{array}$ & 55.14 & 0 & $\mathrm{M}$ & $\mathrm{VL}$ & 45.95 & 0 & $\mathrm{M}$ & $\mathrm{VL}$ & Yellow & Green & Green \\
\hline MS & monopoly by suppliers & 64.86 & 20 & $\mathrm{H}$ & $\mathrm{L}$ & 57.57 & 40 & $\mathrm{M}$ & $\mathrm{M}$ & Yellow & Green & Yellow \\
\hline NP & number of projects going at the same time & 70 & 30 & $\mathrm{H}$ & $\mathrm{L}$ & 64.86 & 60 & $\mathrm{H}$ & $\mathrm{H}$ & Red & Yellow & Yellow \\
\hline PS & political situation & 64.32 & 0 & $\mathrm{H}$ & $\mathrm{VL}$ & 34.05 & 0 & $\mathrm{~L}$ & $\mathrm{VL}$ & Yellow & Green & Green \\
\hline PL & project location & 28.92 & 0 & $\mathrm{~L}$ & $\mathrm{VL}$ & 21.89 & 0 & $\mathrm{~L}$ & $\mathrm{VL}$ & Green & Green & Green \\
\hline SCI & social and cultural impacts & 23.24 & 0 & $\mathrm{~L}$ & $\mathrm{VL}$ & 21.35 & 0 & $\mathrm{~L}$ & $\mathrm{VL}$ & Green & Green & Green \\
\hline
\end{tabular}

*Survey, **Actual

The analysis of the identified 45 factors of the survey risk mapping, indicated that only 2 factors were located in the green zone, 23 factors were located in the yellow zone, and 20 factors were located in the red zone of the risk map. The actual data risk mapping, had 13 factors in the green zone, 10 in the yellow zone and 22 were located in the red zone. The last risk mapping was for the combined results and it showed 10 factors in the green zone, 19 in the yellow zone; and 16 factors were located in the red zone of the risk map.

\section{Ranking of Cost Overrun Factors and Groups}

To calculate the weighted indices for severity and frequency of cost overrun factors, the paper employed the methodology used by Abd El-Razek et al. (2008) and Le-Hoai et al. (2008). They defined an important index (I.I) as the product of severity and frequency indices, i.e.

$$
\text { Importance Index (II) }=(\text { Severity Index }) x(\text { Frequency Index })
$$

The cost overrun factors were ranked according to their Importance Index as shown in Table 5, whereas the eight groups of cost overrun were ranked in Table 6 .

Table 5. Ranking of Cost Overrun Factors Based on the Important Index of the Combined Data

\begin{tabular}{llllllll}
\hline Code & $\begin{array}{l}\text { I.I\% } \\
\text { Survey }\end{array}$ & $\begin{array}{l}\text { I.I\% } \\
\text { Actual }\end{array}$ & $\begin{array}{l}\text { I.I\% } \\
\text { Combined }\end{array}$ & Factors & $\begin{array}{l}\text { I.I\% } \\
\text { Survey }\end{array}$ & $\begin{array}{l}\text { I.I\% } \\
\text { Actual }\end{array}$ & $\begin{array}{l}\text { I.I\% } \\
\text { Combined }\end{array}$ \\
\hline FDC & 76.44 & 60.00 & 68.22 & SM & 34.53 & 30.00 & 32.27 \\
MDC & 58.07 & 70.00 & 64.03 & LCMP & 32.46 & 32.00 & 32.23 \\
DS & 67.45 & 51.43 & 59.44 & NP & 45.41 & 18.00 & 31.70 \\
PSMS & 51.83 & 66.67 & 59.25 & PDDD & 34.89 & 28.00 & 31.45 \\
IQT & 53.02 & 65.00 & 59.01 & CC & 25.86 & 32.00 & 28.93 \\
ITCE & 56.04 & 60.00 & 58.02 & LA & 29.89 & 24.00 & 26.95 \\
SSW & 54.44 & 52.00 & 53.22 & LNC & 45.23 & 8.00 & 26.62 \\
DPAD & 46.85 & 40.00 & 50.81 & SIFP & 32.34 & 18.00 & 25.17 \\
IDTT & 44.93 & 50.00 & 47.46 & IS & 47.89 & 0.00 & 23.94 \\
LP & 56.43 & 36.00 & 46.22 & MS & 37.34 & 8.00 & 22.67 \\
DDM & 26.65 & 65.00 & 45.82 & STP & 35.97 & 8.00 & 21.98 \\
PPM & 53.05 & 36.00 & 44.53 & PFCS & 26.68 & 16.00 & 21.34 \\
LOE & 43.96 & 45.00 & 44.48 & EW & 23.34 & 16.00 & 19.67 \\
MED & 35.19 & 53.33 & 44.26 & EAF & 30.50 & 8.00 & 19.25 \\
LDME & 43.17 & 42.67 & 42.92 & FPM & 38.37 & 0.00 & 19.19 \\
DPPO & 32.20 & 53.33 & 42.76 & EI & 32.31 & 0.00 & 16.15 \\
CF & 29.62 & 55.00 & 42.31 & FDO & 29.38 & 0.00 & 14.69 \\
LCOP & 33.92 & 42.00 & 37.96 & IPRM & 25.33 & 0.00 & 12.67 \\
CSP & 34.23 & 40.00 & 37.12 & PS & 21.91 & 0.00 & 10.95 \\
IPS & 49.10 & 25.00 & 37.05 & GP & 19.08 & 0.00 & 9.54 \\
DPS & 42.25 & 30.00 & 36.12 & PL & 6.33 & 0.00 & 3.17 \\
HCL & 34.11 & 36.00 & 35.06 & SCI & 4.96 & 0.00 & 2.48 \\
IMC & 48.30 & 18.00 & 33.15 & & & & \\
\hline & & & & & & & \\
\hline
\end{tabular}


Table 6. Groups of Cost Overrun Ranked Using Combined Average Important Index

\begin{tabular}{llll}
\hline S.N. & Code & Group & $\begin{array}{l}\text { Average of the } \\
\text { combined I.I }\end{array}$ \\
\hline 1 & DDF & Design and documentation Related Factors & 48.44 \\
2 & CSM & Contractor's site Management Related Factors & 47.42 \\
3 & PMCA & Project Management and Contract Administration & 46.62 \\
4 & HR & Related Factors & 36.68 \\
5 & ICT & Informan Resources (Workforce) Related Factors & 31.78 \\
6 & FIN & Financial Management Related Factors & 31.02 \\
7 & NHR & Non-Human Resource Related Factors & 28.41 \\
8 & EV & Environmental factors & 15.56 \\
\hline
\end{tabular}

\section{Anal ysis of Results by Data Source}

In order to assess the cost overrun causes by each data source independently, data were analyzed separately. This helped in identifying the degree of agreement between participant's opinions and actual projects data. The frequency (likelihood) index, severity (impact) index and importance index were calculated and causes were ranked accordingly as shown in Table 7.

Table 7. Ranking of Top 10 Cost Overrun Factors

\begin{tabular}{|c|c|c|c|}
\hline S.N & Survey data based ranking & Actual data based ranking & Combined data ranking \\
\hline 1 & Frequent design changes & Mistakes during construction & Frequent design changes \\
\hline 2 & Schedule delay & Poor site management and supervision & Mistakes during construction \\
\hline 3 & Mistakes during construction & Delays in decisions making & Schedule delay \\
\hline 4 & Labour productivity & Inaccurate quantity take-off & Poor site management and supervision \\
\hline 5 & $\begin{array}{l}\text { Inaccurate time and cost estim } \\
\text { ates }\end{array}$ & Frequent design changes & Inaccurate quantity take-off \\
\hline 6 & Shortage of site workers & Inaccurate time and cost estimates & Inaccurate time and cost estimates \\
\hline 7 & Poor project management & Cash flow & Shortage of site workers \\
\hline 8 & Inaccurate quantity take-off & Mistakes and errors in design & Delay preparation and approval of drawings \\
\hline 9 & $\begin{array}{l}\text { Poor site management and } \\
\text { supervision }\end{array}$ & Delay in progress payment by owner & Incomplete design at the time of tender \\
\hline 10 & $\begin{array}{l}\text { Inadequate planning and sched } \\
\text { uling }\end{array}$ & Shortage of site workers & Labour productivity \\
\hline
\end{tabular}

"Frequent design changes" was considered as the most important factor of cost overrun causes regarding the survey and combined results. Frequent design changes can affect the project's estimated budget and its consequences involve not only the work package for which the change is directed, but other work packages and overhead functions as well, and for sure, it introduces a delaying event into the schedule.

"Mistakes during construction" came first in actual data and third in respondent's opinions, which can be explained by the amount of reworks, delays and subsequent claims that can cause. "Inaccurate time and cost estimates" falls in the middle of the most important factors of cost overrun causes according to the overall results. Many construction companies suffer from lack of engineers understanding of cost and value and the subsequent cost implications of what is being included in the design, and estimators who are inexperienced with estimating process or Bahrain market. But even with experienced estimators some companies tend to include unrealistically low allowances, in order to keep their bids attractive. Another factor falls in the middle of the most important factors is the "Shortage of site workers", the labour shortage has a high price for construction businesses, it leads to long lead time, and causes loss of works, therefore in Bahrain over time is very familiar practice in all construction firms, and if this isn't enough they head to rent labour with higher expenses; and that leads to huge cost escalation. The causes "Inaccurate quantity take-off" and "Poor site management and supervision" record a high importance in all data as well, however the rest of causes aren't agreed on. 


\section{Conclusion and Recommendations}

This paper aimed to determine factors leading to cost overruns in Bahrain construction industry, through conducting a questionnaire survey and examining of 40 actual construction projects. After a careful literature review, several factors affecting cost overruns were identified and two risk maps for each data source were created. The combined risk maps results showed that 16 out of 45 factors were concluded as critical factors. Factors of cost overrun were then ranked based on their importance index according to their frequency of occurrence and impact on cost overrun. The paper found that frequent design changes, was the highest contributing risk factor to project cost overrun in construction projects. To further manage this factor a detai led feedback from similar previously constructed projects must be considered, site surveys and measurements must be assured, and construction and maintenance engineers should be involved as a part of the design team from the start to eliminate most of the changes. Many recommendations can be specified to construction practitioners, in order to complete construction projects within the budget, such as the use of Risk Assessment and cost control when estimating construction projects, which will help decision makers to define unforeseen situations more reliably ahead of time, so that corrective measures can be better taken into account in project design and estimations. Prioritizing of cost overrun factors in projects leads to better risk contingency weightings in budget estimates. Total cost should be carefully evaluated before undertaking a construction project contract. A contract price should not be over the financial ability of the company. Any financial problem in the project expenditures and payments will cause delay and cost overrun accordingly. Finally, the tight control of any construction project can limit variation in works during construction, and this is absolutely necessary for successful financial outcomes of projects.

\section{References}

Abd, El-Razek, M., Bassioni, H., \& Mobarak, A. (2008). Causes of Delay in Building Construction: Projects in Egypt. Journal of Construction Engineering and Management-ASCE, 134(11), 831-841.

Arditi, D., Akan, G., \& Gurdamar, S. (1985). Cost Overruns in Public Projects. International Journal of Project Management, 3(4), 218-224.

Bahrain Economic Yearbook. (2014). Bahrain Economic Development Board. http://www.bahrainedb.com/.

Elinwa, U., \& Buba, S. (1993). Construction Cost Factors in Nigeria. Journal of Construction Engineering and Management, 119(4) 698-714.

Flyvbjerg, B., Berzelius, N., \& Rothengatter, W. (2003). Megaprojects and Risk: An Anatomy of Ambition. Cambridge, United Kingdom.

Flyvbjerg, B., Holm, M. S., \& Buhl, S. (2002). Underestimating Costs in Public Works Projects. Journal of the American Planning Association.

Jackson, S. (2002). Project Cost Overruns and Risk Management. School of Construction Management and Engineering. The University of Reading, White knights, United Kingdom.

Koushki, P. A., Al-Rashid, K., \& Kartam, N. (2004). Delays and Cost Increases in the Construction of Private Residential Projects in Kuwait. Kuwait University.

Le-Hoai, L., Lee, Y. D., \& Lee, J. Y. (2008). Delay and Cost Overruns in Vietnam Large Construction Projects: A Comparison with Other Selected Countries. Journal of Construction Management, 367-377.

Okpala, D., \& Aniekwu, A. (1988), Cause of High Cost of Construction in Nigeria. Journal of Construction Engineering and Management, ASCE, 114(2), 223-34.

The U.S. Federal Highway Administration Office of International Programs (FHWA), (2007). Guide to the Risk Assessment and Allocation Process in Highway Construction. Report, July, 2007. Retrieved from http://international.fhwa.dot. gov/riskassess/images/riskmatrix.cfm

\section{Copyrights}

Copyright for this article is retained by the author(s), with first publication rights granted to the journal.

This is an open-access article distributed under the terms and conditions of the Creative Commons Attribution license (http://creativecommons.org/licenses/by/4.0/). 